\title{
Fate of napropamide herbicide in selected Malaysian soils.
}

\begin{abstract}
This study was carried out to determine the sorption-desorption, degradation and leaching of napropamide in selected Malaysian soils. The sorption capacities of the selected Malaysian soils for napropamide were the following in descending order: Linau > Teringkap > Gunung Berinchang > Jambu > Rudua > Baging soil. The results indicate that napropamide degradation decreased with increasing soil sorption capacity. Napropamide was leached out earlier in the Baging soil than the other soils. Overall, the application of napropamide in the selected Malaysian soils would not pose a threat to the environment except in soil with low organic matter and clay content and high hydraulic conductivity, such as the Baging soil.
\end{abstract}

Keyword: Sorption; Degradation; Leaching; Clay; Organic matter. 